Fastabiq: Jurnal Studi Islam

ISSN 2723-0228

Volume 1 Nomor 2 Nopember 2020

Halaman 145-156

\title{
MODEL PENGELOLAAN PENDIDIKAN KARAKTER DI SEKOLAH PADA MASA PANDEMI
}

\author{
Ni'mawati $^{1}$, Fitri Handayani ${ }^{2}$, Aan Hasanah ${ }^{3}$ \\ ${ }^{1}$ STAI Siliwangi Bandung \\ nimawati15@stai-siliwangi.ac.id \\ ${ }^{2}$ UIN Sunan Gunung Djati Bandung \\ fitrihandayani078@gmail.com \\ ${ }^{3}$ UIN Sunan Gunung Djati Bandung \\ aan.hasanah@uinsgd.ac.id
}

\begin{abstract}
Character education is important to be developed continuously. Schools as formal educational institutions are the printers to create an ideal nation. The teacher has a very strategic position in building the character of students. In order for the management of character education in schools to be optimal, effective, and efficient, effective and efficient management activities are needed as well. Character education is very important for students. Therefore, even though currently during the Covid19 pandemic, character education must still be conveyed to students. The purpose of this study was to analyze the character education management model in schools during the pandemic. This research uses descriptive analysis method with a qualitative approach and library data sources. The results of this study are that the character education management model in schools during the pandemic can be implemented by: First, collaboration between schools and parents of students must be continuously established, increased in intensity and quality. Both the use of information and communication technology (ICT) are both used for learning based on character, and can be used as well as possible to develop the students' skills. The third Problem Based Learning (PBL) builds a sense of responsibility and makes students not easily bored in online learning because it builds motivation in overcoming existing problems.
\end{abstract}

Keywords: Pandemic, character education, management.

\begin{abstract}
Abstrak
Pendidikan karakter di sekolah penting untuk dikembangkan secara terus-menerus. Sekolah sebagai lembaga pendidikan formal merupakan pencetak generasi bangsa yang ideal. Guru memiliki posisi yang sangat strategis dalam membangun karakter peserta didik. Agar pengelolaan pendidikan karakter di sekolah dapat optimal, efektif, dan efisien, maka diperlukan kegiatan manajemen yang efektif dan efisien pula. Pendidikan karakter sangat penting bagi peserta didik. Oleh karena itu meskipun sekarang ini dalam masa pandemi Covid-19 pendidikan karakter tetap harus tersampaikan ke peserta didik. Tujuan penelitian ini yaitu untuk menganalisis model pengelolaan pendidikan karakter di sekolah pada masa pandemi. Penelitian ini menggunakan metode analisis deskriptif dengan pendekatan kualitatif dan sumber data kepustakaan. Hasil penelitian ini adalah bahwa model pengelolaan pendidikan karakter di sekolah pada masa pandemi dapat dilaksanakan dengan cara: Pertama kolaborasi antara sekolah dengan orang tua siswa harus terus-menerus dijalin, dipererat, dan ditingkatkan intensitas dan kualitasnya. Kedua pemanfaatan teknologi informasi dan komunikasi (TIK) sebagai sarana untuk pembelajaran nili-nilai dasar pendidikan karakter, dan dapat dimanfaatkan sebaik-baiknya untuk mengembangkan kreativitas peserta didik. Ketiga Problem Based Learning (PBL) membangun rasa tanggung jawabdan menjadikan siswa tidak mudah jenuh dalam belajar online karena terbangun motivasi dalam memperoleh pemecahan masalah yang dihadapi.
\end{abstract}

Keywords: Pandemi, pendidikan karakter, pengelolaan. 


\section{PENDAHULUAN}

Pendidikan merupakan suatu proses dalam mengembangkan diri tiap individu untuk dapat hidup dan melangsungkan kehidupan. Siswa dididik agar menjadi orang yang berguna baik bagi negara, nusa dan bangsa. Bangsa Indonesia tidak hanya meletakkan pendidikan sebagai sesuatu yang penting, tetapi bangsa Indonesia berusaha merealisasikan konsep pendidikan dengan cara pembinaan, pelatihan dan pemberdayaan sumber daya manusia (SDM) Indonesia secara berkelanjutan dan merata. Undang undang No. 20 tahun 2003 tentang Sisdiknas yang menyatakan bahwa tujuan pendidikan adalah agar menjadi manusia yang beriman dan bertakwa kepada Tuhan Yang Maha Esa, berakhlak mulia, sehat, berilmu, cakap, kreatif, mandiri, dan menjadi warga negara yang demokratis serta bertanggung jawab.

Ketersediaan SDM yang berkarakter merupakan kebutuhan yang amat urgen. Ini dilakukan untuk mempersiapkan tantangan global dan daya saing bangsa. Pendidikan karakter dipengaruhi oleh faktor yang sangat kompleks mulai dari pendidikan dalam keluarga, lingkungan tempat tinggal, dan pendidikan di sekolah. ${ }^{1}$

Untuk mencapai hasil yang maksimal, pendidikan karakter di sekolah penting untuk dikembangkan secara terus-menerus. Karena sekolah sebagai lembaga pendidikan formal merupakan pencetak generasi bangsa yang ideal. ${ }^{2}$ Dalam pengelolaan pendidikan karakter di sekolah, semua komponen (stakeholders) terlibat. Komponen-komponen pendidikan yaitu isi kurikulum, proses pembelajaran dan penilaian, kualitas hubungan, penanganan atau pengelolaan mata pelajaran, pengelolaan sekolah, pelaksanaan aktivitas, pemberdayaan sarana prasarana, pembiayaan, dan etos kerja seluruh warga dan lingkungan sekolah. Agar pengelolaan pendidikan karakter di sekolah dapat optimal, efektif, dan efisien, maka diperlukan kegiatan manajemen yang efektif dan efisien pula.

Pendidikan karakter di sekolah juga erat kaitannya dengan pengelolaan sekolah. Pengelolaan di sini mencakup fungsi manajemen pendidikan karakter mulai dari perencanaan, pengorganisasian, pelaksanaan, dan pengendalian atau evaluasinya. Dengan demikian, manajemen sekolah merupakan proses yang efektif dalam pendidikan karakter di sekolah.

Pendidikan karakter sangat penting bagi peserta didik. Oleh karena itu meskipun sekarang ini dalam masa pandemi Covid-19 pendidikan karakter tetap harus tersampaikan ke peserta didik. Berkaitan dengan pembelajaran pada masa pandemi ini, Mendikbud Nadim Anwar Makarim menerbitkan Surat Edaran Nomor 4 Tahun 2020 tentang Pelaksanaan Pendidikan Dalam Terkait belajar dari rumah pada masa darurat Corona Virus Disease (Covid-19), Mendikbud menekankan bahwa pembelajaran dalam jaringan (daring) atau jarak jauh dilaksanakan untuk memberikan pengalaman belajar yang bermakna bagi siswa, tanpa terbebani tuntutan menuntaskan seluruh capaian kurikulum untuk kenaikan kelas maupun kelulusan. Mendikbud menganjurkan bagi daerah yang sudah melakukan belajar dari rumah agar dipastikan guru juga mengajar dari rumah untuk menjaga keamanan para guru. ${ }^{3}$ 
Masa pandemi pendidikan harus menerapkan pembalajaran jarak jauh, siswa harus belajar dari rumah, guru harus mengajar dari rumah. Hal ini memerlukan penyesuaian dari semua pihak; pengelola sekolah, guru, orangtua/wali siswa dan siswa, Dari penelitian yang dilakukan oleh Takhroji Aji diketahui terdapat banyak keluhan yang disampaikan oleh orang tua siswa berkaitan dengan penyampaian pendidikan karakter di rumah. ${ }^{4}$ Dengan demikian perlu model pengelolaan pendidikan karakter yang sesuai dengan kondisi pandemi sekarang ini.

\section{METODE PENELITIAN}

Penelitian ini menggunakan metode analisis deskriptif. Penelitian ini mendeskripsikan tentang model pengelolaan pendidikan karakter pada masa pandemi. Penelitian ini menggunakan sumber data sekunder, diantaranya adalah web, jurnal, dan buku-buku yang berkaitan dengan pendidikan karakter. Pendekatan yang digunakan dalam penelitian ini adalah kualitatif. Analisis data kualitatif ini terdiri dari beberapa alur kegiatan yaitu kategorisasi, reduksi data, penyajian data dan penarikan kesimpulan.

\section{PEMBAHASAN}

Dalam Panduan Pelaksanaan Pendidikan Karakter, pendidikan karakter adalah pendidikan nilai, pendidikan budi pekerti, pendidikan moral, pendidikan watak yang bertujuan mengembangkan kemampuan seluruh warga sekolah untuk memberikan keputusan baik-buruk, keteladanan, memelihara apa yang baik dan mewujudkan kebaikan itu dalam kehidupan sehari-hari dengan sepenuh hati. ${ }^{3}$ Gunawan mendefinisikan pendidikan karakter sebagai upaya-upaya yang dirancang dan dilaksanakan secara sistematis untuk menanamkan nilai-nilai perilaku peserta didik yang berhubungan dengan Tuhan Yang Maha Esa, diri sendiri, sesama manusia, lingkungan, dan kebangsaan yang terwujud dalam pikiran, sikap, perasaan, perkataan, dan perbuatan berdasarkan norma-norma agama, hukum, tata krama, budaya, dan adat istiadat. ${ }^{5}$

Sebagaimana yang dijelaskan Hakam, pendidikan nilai adalah pendidikan yang mempertimbangkan objek dari sudut pandang moral yang meliputi etika dan norma-norma yang meliputi estetika, yaitu menilai objek dari sudut pandang keindahan dan selera pribadi, serta etika yaitu menilai benar/salahnya dalam hubungan antar pribadi. ${ }^{6}$ Tujuan pendidikan nilai menurut Suparno, adalah menjadikan manusia berbudi pekerti. ${ }^{7}$ Mulyana dan Hakam menambahkan bahwa pendidikan nilai bertujuan untuk membantu peserta didik mengalami dan menempatkan nilai-nilai secara integral dalam kehidupan mereka. ${ }^{8}$

Sementara itu menurut Anies Baswedan, pendidikan karakter merupakan kebiasaan bukan sekadar ilmu pengetahuan. Pendidikan karakter tidak dapat hanya diajarkan di ruang kelas, namun juga di ruang kehidupan. Pendidikan karakter abad 21 menanamkan kebiasaan. Setelah kebiasaan, nanti akan menjadi karakter dan akhirnya terbentuk budaya. Pendidikan karakter selama ini hanya dipahami sebagian besar masyarakat sebagai pendidikan moral seperti jujur, sopan, atau hormat ke orang tua. Padahal pendidikan karakter kinerja tidak kalah penting untuk diajarkan dan dibiasakan kepada anak-anak. Karakter kinerja seperti kerja keras, disiplin, kerja tuntas, tak mudah menyerah 


\section{Fastabiq: Jurnal Studi Islam}

ISSN 2723-0228

Volume 1 Nomor 2 Nopember 2020

dan lainnya. ${ }^{10}$

Pendidikan memegang peranan penting dalam membentuk akhlak mulia dan luhur bagi peserta didik. Keberhasilan dalam pendidikan karakter sendiri dipengaruhi oleh berbagai faktor, seperti cara atau pendekatan yang dipergunakan dalam menyampaikannya. ${ }^{11}$ Menurut Suparno, dkk ada empat model pendekatan penyampaian pendidikan karakter, yaitu: 1) Model sebagai mata pelajaran tersendiri (monolitik), dimana pendidikan karakter dianggap sebagai mata pelajaran tersendiri. 2) Model terintegrasi dalam semua mata pelajaran, yaitu dalam menyampaikan pendidikan karakter adalah disampaikan secara terintegrasi dalam setiap bidang pelajaran, dan oleh karena itu menjadi tanggunmg jawab semua guru. 3) Model di luar pengajaran, yang lebih mengutamakan pengolahan dan penanaman nilai melalui suatu kegiatan untuk dibahas dan kemudian dibahas nilai-nilai hidupnya. 4) Model gabungan, adalah menggabungkan antara model terintegrasi dan model di luar pelajaran secara bersama. ${ }^{12}$

Masa pandemi, pendidikan di Indonesia beralih melalui daring (online). Hampir semua jenjang mengikuti pembelajaran melalui platform yang terdapat di komputer. Banyak pembelajaran yang diambil ketika mengikuti belajar online. Sekolah penting untuk membuka wawasan tentang pendidikan karakter melalui pendidikan jarak jauh, dengan membekali keterampilan guru dalam pelaksanaan pembentukan karakter melalui pendidikan jarak jauh. Dengan demikian sekolah dan konselor dalam menumbuhkan keteladanan nilai-nilai karakter khususnya pada masa belajar di rumah, menginspirasi guru dengan berbagai strategi yang dapat diterapkan sekolah dalam pembentukan karakter.

Pengelolaan pendidikan karakter dapat dikembangkan melalui habituasi yaitu dengan cara diajarkan, dibiasakan, dilatih konsisten, menjadi kebiasaan, menjadi karakter, menjadi budaya. Pelaksanaan ini dapat diterapkan mulai dari rumah, kelas, sekolah, dan masyarakat. Diantara pengembangan model pengelolaan pendidikan karakter masa pandemi dapat diimplementasikan dengan cara sebagai berikut:

1. Kolaborasi antara Sekolah dengan Orang Tua Siswa

Hasil penelitian Takhroji Aji terhadap orang tua murid dari tingkat TK sampai dengan SMU menunjukan orang tua siswa setuju bahwa mereka tidak dapat sepenuhnya melakukan pendidikan karakter terhadap anaknya tanpa bantuan guru. Para orang tua yakin bahwa guru sangat membantu mereka dalam membentuk dan membangun karakter anak-anaknya. Mereka merasa bahwa keberadaan guru dalam membangun karakter anak-anak sangat dibutuhkan. Tanpa adanya peran serta guru maka orang tua tidak dapat secara maksimal membentuk dan membangun karakter anak - anak mereka. 


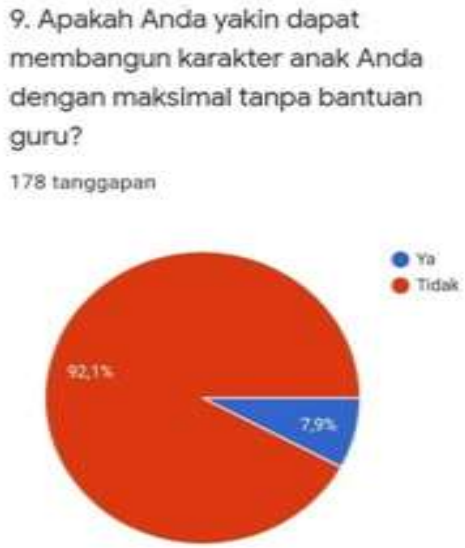

Diagram 1

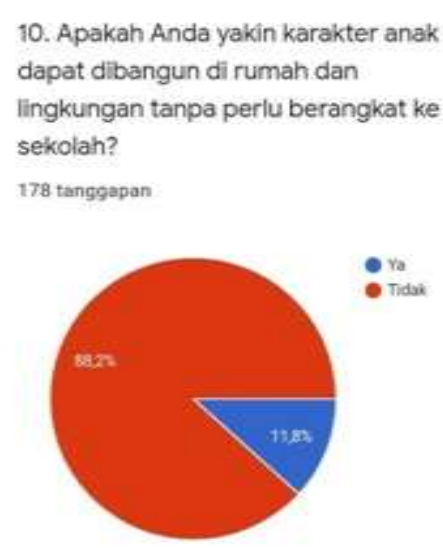

Diagram 2
12. Selama siswa belajar dari rumah apakah Anda merasa masih perlu bantuan guru untuk membangun karakter anak-anak?

178 tanggapan

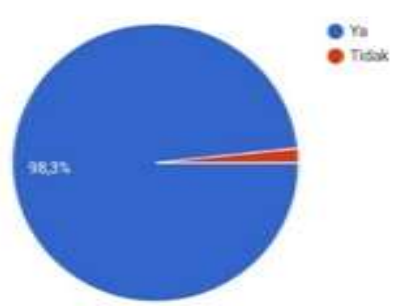

Diagram 3

Keterangan :

Diagram 1 menunjukan dari 178 responden, 92,1\% ( 164 responden) menyatakan bahwa orang tua tidak dapat membangun karakter anak dengan maksimal tanpa peran serta para guru.

Diagram 2 menunjukan dari 178 responden, 88,2\% (157 responden) menyatakan bahwa karakter anak tidak dapat dibangun di rumah dan lingkungan anak tanpa adanya peran serta sekolah. ${ }^{13}$

Dari penelitian tersebut dapat diambil kesimpulan bahwa penting bagi guru untuk bekerja sama dengan orang tua siswa dalam melaksanakan pendidikan karakter terhadap siswa. Orang tua siswa membutuhkan panduan dan arahan dari guru dalam pendidikan karakter untuk anak-anak mereka. Hal itu dapat dilaksanakan di tiap mata pelajaran.

Setiap mata pelajaran selalu ada bagian karakter yang harus dikembangkan. Pihak sekolah memberikan informasi tentang nilai-nilai karakter yang akan ditanamkan. Pendidikan karakter yang diintegrasikan dalam pembelajaran berbagai bidang studi dapat memberikan pengalaman yang bermakna bagi siswa. $^{14}$

Belajar dari pandemi, guru, orang tua dan masyarakat harus bersinergi gotong royong membangun pendidikan. Selain itu, peran guru saat ini yang digantikan orang tua adalah membimbing keteraturan dan kedisiplinan ketika proses belajar, juga memotivasi anak dalam belajar dan menjadi fasilitator yang baik bagi anak dalam belajar. Masa pandemi ini menjadikan pendidikan yang pertama dan utama adalah di rumah. Dalam hal ini sekolah mengambil peran sebagai fasilitator.

Keluarga merupakan kelompok sosial yang pertama dalam kehidupan manusia, tempat pertama dalam belajar dan menyatakan diri sebagai manusia sosial di dalam hubungan interaksi dengan kelompoknya. Pengaruh dominan yaitu distorsi terhadap waktu penjadualan kegiatan pembelajaran peserta didik, baik secara struktur, pembagian tugas dan internalisasi norma-norma. Peran yang selama ini dilaksanakan di satuan pendidikan beralih fungsi di satuan keluarga. ${ }^{15}$ 
Kemandirian anak harus ditumbuhkan, harus ada peran dominan orang tua dalam mendidik siswa, khususnya pada pendidikan karakter. Salah satu yang harus dikembangkan adalah kemandirian. Membuat anak mandiri itu jauh lebih berharga dan bisa menjadi alat untuk berkreativitas. Karena itulah dibutuhkan peran serta orang tua dan guru agar dapat menumbuhkan karakter siswa yang kuat dan tangguh. ${ }^{16}$ Dengan demikian kerja sama antara pihak sekolah dan orang tua siswa harus terus-menerus dijalin, dipererat, dan ditingkatkan intensitas dan kualitasnya. Orang tua siswa memiliki fasilitator atau pemandu dalam mendampingi anaknya dalam pembelajaran di rumah terutama dalam membangun karakter anak. Hal tersebut membantu orang tua siswa mempermudah langkah langkah yang harus diterapkan terhadap anaknya.

\section{Pemanfaatan Teknologi Informasi dan Komunikasi (TIK)}

Pandemi Covid-19 menyebabkan penutupan sekolah-sekolah dalam upaya menghentikan pergerakkan pandemi. Sebagai gantinya, pemerintah telah memberlakukan sistem Pendidikan Jarak Jauh (PJJ). Sistem PJJ yang berbasis teknologi mengharuskan lembaga pendidikan, guru, siswa bahkan orang tua agar cakap teknologi. Hal ini berdampak positif yaitu memicu percepatan transformasi teknologi pendidikan di negeri ini. Penggunaan TIK dalam pendidikan selaras dengan era Revolusi Industri 4.0 yang terus bergerak maju. Percepatan transformasi teknologi pendidikan karena pandemi Corona membuat berbagai platform meluncurkan berbagai aplikasi belajar online guna mendukung PJJ.

Penggunaan TIK di Indonesia memasuki tahap mempelajari berbagai kemungkinan untuk pengembangan dan penerapan teknologi untuk pendidikan. Informasi yang diwakili oleh komputer yang terhubung ke internet sebagai media utama telah mampu memberikan kontribusi yang begitu besar bagi proses pendidikan. Selama masa pandemi ini, banyak hikmah yang bermanfaat terutama dalam hal penggunaan teknologi. Semua pihak di sektor pendidikan harus menyadari peranan penting teknologi dalam mendukung pembelajaran.

Banyak munculnya aplikasi belajar online membuat belajar tetap dapat dilakukan dengan efektif. Aplikasi-aplikasi belajar online dikembangkan dengan penyediaan fitur-fitur yang memudahkan dalam melakoni belajar online.

Dalam pengembangan model pengelolaan pendidikan karakter harus keluar dari zona nyaman untuk berinovasi menciptakan kreativitas, harus melakukan adaptasi yang lebih dengan penggunaan media teknologi. Peran guru yang dapat dilakukan saat pembelajaran di rumah adalah menyiapkan materi pembelajaran, mengajarkan dan mengevaluasi pembelajaran. Penting bagi guru untuk meningkatkan kreativitas untuk pembelajaran di rumah agar tidak terlalu bosan.

Dengan pembelajaran jarak jauh menuntut semua pihak baik guru maupun siswa dapat beradaptasi terutama dengan media elektronik sebagai alat pembelajaran. Sisi positif dari kondisi ini mendorong guru dan siswa memiliki kecakapan personal bidang teknologi informasi dan komunikasi. Hakikat kecakapan personal (personal skill) dalam konsepsi ini merupakan kecakapan diri yang diperlukan oleh individu agar seseorang dapat eksis dan mampu mengambil peluang yang 


\section{Fastabiq: Jurnal Studi Islam}

ISSN 2723-0228

Volume 1 Nomor 2 Nopember 2020

positif dalam kondisi kehidupan yang berubah dengan sangat cepat. ${ }^{17}$

Dalam rangka pembangunan sumberdaya manusia yang berkualitas, bermartabat, dan berkarakter, pemanfaatan TIK perlu dijaga agar tidak mengganggu pembentukan karakter peserta didik, melainkan justru mendukungnya. Dengan demikian pemanfaatan TIK dalam pendidikan perlu direncanakan, dilaksanakan, dan dievaluasi secara berkelanjutan.

Menurut Suwarsih Madya, untuk menjaga agar pemanfaatan TIK tetap memberikan kontribusi signifikan terhadap; pengembangan peserta didik menjadi manusia berkarakter dan berkecerdasan intelektual; dan pemberdayaan pendidik dan tenaga kependidikan terkait, hendaknya diterapkan prinsip-prinsip berikut: a) Pemanfaatan TIK dalam pendidikan sebaiknya mempertimbangkan karaktersitik peserta didik, pendidik, dan tenaga kependidikan dalam keseluruhan pembuatan keputusan TIK, b) Pemanfaatan TIK sebaiknya dirancang untuk memperkuat minat dan motivasipengguna untuk menggunakannya semata guna meningkatkan dirinya, baik dari segi intelektual, spiritual (rohani), sosial, maupun ragawi, c) Pemanfaatan TIK sebaiknya menumbuhkan kesadaran dan keyakinan akan pentingnya kegiatan berinteraksi langsung dengan manusia (tatap muka), dengan lingkungan sosial-budaya (pertemuan, museum, tempat-tempat bersejarah), dan lingkungan alam (penjelajahan) agar tetap mampu memelihara nilai-nilai sosial dan humaniora (seni dan budaya), dan kecintaan terhadap alam sebagai anugerah dari Tuhan Yang Maha Esa, d) Pemanfaatan TIK sebaiknya menjaga bahwa kelompok sasaran tetap dapat mengapresiasi teknologi komunikasi yang sederhana dan kegiatan-kegiatan pembelajaran tanpa TIK karena tuntutan penguasaan kompetensi terkait dalam rangka mengembangkan seluruh potensi siswa secara seimbang, e) Pemanfaatan TIK sebaiknya mendorong pengguna untuk menjadi lebih kreatif dan inovatif sehingga tidak hanya puas menjadi konsumen informasi berbasis TIK. ${ }^{18}$

Guru hendaknya dalam menyampaikan materi dengan metode yang menarik dan interaktif sehingga dapat menstimulus kreatifitas siswa. Hal itu menjadikan implementasi pendidikan karakter melalui TIK mencapai tujuan. Guru sebagai fasilitator. Pembelajaran lebih berpusat pada peserta didik bukan pada guru. Proses pelaksanaan pembelajaran melalui TIK, peserta didik selain diarahkan mencari dan memperoleh informasi juga diarahkan agar memiliki kemampuan untuk menciptakan dan memberikan informasi di internet dengan berbagai karya baik bentuk tulisan atau video. Dengan demikian kreatifitas siswa akan tergali dan teroptimalkan.

Untuk tercapainya hal di atas guru dapat memberikan teladan dengan membuat konten-konten pembelajaran melalui blog dan video platform youtube. Yang demikian itu banyak memberikan manfaat bagi siswa karena materi dapat dilihat berulangkali. Sehingga pesan lilai yang terkandung di dalam materi pembelajaran lebih mungkin terserap oleh siswa. Dengan melihat keteladanan yang didapat dari gurunya dalam pemanfatan TIK dalam pembelajaran, peserta didik pun akan terbiasa dan mengikuti dalam pemanfaatan TIK. Pembiasaan tersebut merupakan pembinaan pendidikan budaya dan karakter yang terus dikembangkan oleh para guru. 


\section{Fastabiq: Jurnal Studi Islam}

ISSN 2723-0228

Volume 1 Nomor 2 Nopember 2020

Pembelajaran melalui TIK akan melatih peserta didik mampu mendengar, berbicara, membaca, dan menulis dengan baik. Keterampilan tersebut sangat bermanfaat, mampu menyampaikan pesan kepada masyarakat secara luas. TIK sebagai sarana untuk pembelajaran nili-nilai dasar pendidikan karakter, dan dapat dimanfaatkan sebaik-baiknya untuk mengembangkan kreativitas peserta didik.

\section{Problem Based Learning (PBL)}

Pengertian Problem Based Learning (PBL) didasarkan pada teori psikologi kognitif terutama berlandaskan teori Piaget dan Vigotsky (konstruktivisme). Bahwa peserta didik belajar mengkonstruksi pengetahuannya melalui interaksi dengan lingkungannya. Problem Based Learning (PBL) dapat membuat siswa belajar melalui upaya penyelesaian masalah dunia nyata (real world problem) secara terstruktur untuk mengonstruksi penegatahuan peserta didik. Pembelajaran ini menuntut peserta didik untuk aktif melakukan penyelidikan dalam menyelesaikan permasalahan dan pendidik berperan sebagai fasilitator atau pembimbing. ${ }^{19}$

Melalui PBL melatih siswa menyusun sendiri pengetahuannya, mengembangkan keterampilan memecahkan masalah. Selain itu, dengan pemberian masalah autentik, siswa dapat membentuk makna dari bahan pelajaran dengan proses belajar dan menyimpannya dalam ingatan sehingga suatu saat dapat digunakan lagi. Jadi Problem Based Learning atau pembelajaran berbasis masalah adalah suatu strategi pembelajaran yang menjadikan masalah dunia nyata sebagai suatu konteks bagi peserta didik untuk belajar tentang cara berpikir kritis dan keterampilan dalam memecahan masalah, serta untuk mendapatkan pengetahuan dan konsep yang esensial dari materi pelajaran. ${ }^{20}$

Dibangunnya pemikiran dasar pembelajaran dengan penerapan Problem Based Learning adalah untuk menyelesaikan masalah. Dengan demikian orang yang memiliki kemauan tinggi untuk menyelesaikan masalah termasuk orang yang bertanggung jawab. Dan tanggung jawab itu adalah nilai dari sebuah karakter. Sehingga Problem Based Learning memiliki karakter utama yaitu tanggung jawab. $^{21}$

Nilai karakter tanggung jawab ini menjadi gerbang untuk membuka nilai-nilai karakter lainnya apabila diterapkan dalam pembelajaran. Karena Problem Based Learning yang masih asli hanya mengandung satu nilai karakter secara implisit, maka perlu pengembangan Problem Based Learning secara lebih kompleks. Dengan demikian pengembangan Problem Based Learning akan mengembangkan hal-hal di bawah ini.

Pertama, Problem Based Learning dikaji dan digali untuk diaktualisasikan dalam pembelajaran, sehingga nila-nilai karakter tersebut dapt ditanamkan atau diinternalisasikan ke dalam diri peserta didik. Dalam hal ini, Problem Based Learning dianggap seolah-olah telah ada atau mengandung muatan nilai karakter di dalamnya.

Kedua, Problem Based Learning dapat dimodifikasi dan dikembangkan secara kreatif agar memuat nilai-nilai karakter lebih kompleks. Artinya, Problem Based Learning dapat diisi muatan nilai karakter dari luar yang sesuai kepentingan pendidik dalam pembelajaran. Dalam hal ini, Problem 


\section{Fastabiq: Jurnal Studi Islam}

ISSN 2723-0228

Volume 1 Nomor 2 Nopember 2020

Based Learning diperlukan sebagai strategi pembelajran yang netral sehingga dapat diisi dengan muatan nilai-nilai karakter sesuai kepentingan pendidik dan peserta didik. ${ }^{22}$

Problem Based Learning juga merupakan suatu model pembelajaran yang melibatkan peserta didik untuk memecahkan suatu masalah melalui tahap-tahap metode ilmiah. Peserta didik dapat mempelajari pengetahuan yang berhubungan dengan masalah tersebut sekaligus memiliki keterampilan untuk memecahkan masalah.Cara mencapai hasil pembelajaran secara optimal, pembelajaran berbasis masalah perlu dirancang dengan baik mulai dari penyiapan masalah yang sesuai dengan kurikulum yang dikembangkan dikelas,memunculkan masalah dari peserta didik, peralatan yang mungkin diperlukan, dan penilaian yang digunakan. Pengajar yang menerapkan model ini harus mengembangkan diri melalui pengalaman mengelola dikelasnya, melalui pendidikan pelatihan atau pendidikan formal yang berkelanjutan. ${ }^{23}$

Dengan demikian pendidikan karakter melalui PBL pada masa pandemi sangat strategis. Siswa tidak mudah jenuh karena terbangun tanggung jawab dan motivasi dalam memperoleh pemecahan masalah yang dihadapi.

\section{SIMPULAN}

Sekolah merupakan lembaga yang efektif sebagai tempat untuk mencetak generasi penerus yang berkarakter ideal. Tetapi pada masa pandemi Covid-19 sekarang ini dalam menjalankan perannya sekolah mengalami kendala dan hambatan. Pendidikan sekolah dilaksanakan secara jarak jauh. Guru tidak dapat berinteraksi dengan siswa secara langsung. Maka model pengelolaan pendidikan karakter di sekolah pada masa pandemi dapat dilaksanakan dengan cara: Pertama, kolaborasi antara sekolah dengan orang tua siswa harus terus-menerus dijalin, dipererat, dan ditingkatkan intensitas dan kualitasnya. Kedua, pemanfaatan teknologi informasi dan komunikasi (TIK) sebagai sarana untuk pembelajaran nili-nilai dasar pendidikan karakter, dan dapat dimanfaatkan sebaik-baiknya untuk mengembangkan kreativitas peserta didik. Ketiga, Problem Based Learning (PBL) membangun rasa tanggung jawab dan menjadikan siswa tidak mudah jenuh dalam belajar online karena terbangun motivasi dalam memperoleh pemecahan masalah yang dihadapi.

Dalam penelitian ini fokus pada model pengelolaan pendidikan karakter di sekolah pada masa pandemi. Selanjutnya para peneliti berikutnya dapat melakukan penelitian tentang evaluasi terhadap pelaksanaan pendidikan karakter pada pasa pandemi. 


\section{ENDNOTES}

${ }^{1}$ Yudi Kuswandi dan Emma Himayaturohmah, Pembudayaan Nilai-Nilai Islami Dalam Membangun Karakter Bangsa (Studi Kasus di Sekolah Menengah Kejuruan Negeri 1 Cimahi) . Tatar Pasundan: Jurnal Diklat Keagamaan Bandung. Vol. 12 (34)2018: 268.

${ }^{2}$ Ramin, Karakteristik Pendidikan Karater Siswa Pada Jenjang Pendidikan Dasar. Tatar Pasundan: Jurnal Diklat Keagamaan. Vol. 12 (32) 2018.

3 Takhroji Aji, dalam https://bdkjakarta.kemenag.go.id/berita/pendidikan- karakter-di-masa-pandemimenjadi-tanggung-jawab-siapa?, diakses tanggal 19 Juli 2020. Pukul 20.01.

4. Takhroji Aji, dalam https://bdkjakarta.kemenag.go.id/berita/pendidikan- karakter-di-masa-pandemimenjadi-tanggung-jawab-siapa?, diakses tanggal 30 Oktober 2020. Pukul 10.11.

5 Kementerian Pendidikan Nasional, Panduan Pelaksanaan Pendidikan Karakter (Jakarta: Pusat Kurikulum dan Perbukuan, 2011), hal. 6.

6 Heri Gunawan, Pendidikan Karakter, Konsep dan Implementasi, (Bandung: Alfabeta, 2014), hal. 28.

7 K. A. Hakam, Pendidikan Nilai. (Bandung: CV Maulana, 2005), hal. 5.

6 Suparno, Keterampilan Dasar Menulis, (Jakarta: Universitas Terbuka, Departemen Pendidikan Nasional, 2002), hal. 75.

8 R. Mulyana, Mengartikulasikan Pendidikan Nilai, (Bandung: CV. Alfabeta, 2004), hal. 117.

9 K. A. Hakam, Pendidikan Nilai. (Bandung: CV Maulana, 2005), hal. 8.

10 Anies Baswedan, dalam https://www.merdeka.com/jakarta/anies-baswedan-pendidikan-karakterbukan-sekadar-ilmu-pengetahuan.html. diakses tanggal 19 Juli 2020. Pukul 20.34.

$11 \mathrm{H}$. Akhmad Gafuri. Pengembangan Model Manajemen Pendidikan Karakter Dengan Teknik Pendampingan Guru Pada Sekolah Dasar.Jurnal Paradigma, Volume 11, Nomor 2, Juli 2016. Hal. 55. 12 Suparno, Keterampilan Dasar Menulis, (Jakarta: Universitas Terbuka, Departemen Pendidikan Nasional, 2002), hal. 42-44.

13 Takhroji Aji, dalam https://bdkjakarta.kemenag.go.id/berita/pendidikan- karakter-di-masa-pandemimenjadi-tanggung-jawab-siapa?, diakses tanggal 19 Juli 2020. Pukul 21.24.

14 Darmiyati Zuchdi, Pengembangan Model Pendidikan Karakter Terintegrasi Dalam Pembelajaran Bidang Studi Di Sekolah Dasar. Cakrawala Pendidikan Jurnal Ilmiah Pendidikan No. 3 Mei 2010. Hal. 3.

15 Subarto. Momentum Keluarga Mengembangkan Kemampuan Belajar Peserta Didik Di Tengah Wabah Pandemi Covid-19. 'Adalah Jurnal Hukum dan Keadilan volume 4 nomor 1 2020. Hal. 15.

16 Adit, Albertus, dalam https://www.kompas.com/edu/read/2020/07/06/134752871/di-masapandemi-orangtua-berperan-dalam-pendidikan-karakter-anak, diakses tanggal 15 Juli 2020. Pukul 21.07.

17 Widoyoko, S. E. 2007. "Pengembangan Model Evaluasi Pembelajaran IPS di SMP", Disertasi. Yogyakarta: PPS UNY

$18 \mathrm{https}: / /$ abdiguru.id/pemanfaatan-teknologi-dalam-pendidikan-karakter-di-sekolah. Diakses tanggal 30 Oktober 2020 pukul 16.00.

19 Ridwan Abdullah Sani, Pembelajaran Santifik untuk Implementasi Kurikulum 2013, (Jakarta: Bumi Aksara, 2014), hal.127.

20 Taufikin. Pembentukan Karakter Melalui Pembelajaran Problem Based Learning. Jurnal ThufuLA Volume 5 Nomor 1 Januari - Juni 2017. Hal. 213

21 Taufikin. Pembentukan Karakter Melalui Pembelajaran Problem Based Learning. Jurnal ThufuLA Volume 5 Nomor 1 Januari - Juni 2017. Hal. 213

22 Suyadi. Srategi Pembelajaran Pendidikan Karakter, ( Bandung: Remaja Rosdakarya, 2015). Cet. III.Hal. 134

23 Ahmad Sahal Fuadi. Penerapan Model Pembelajaran Problem Based Learning (PBL) Pada 


\section{Fastabiq: Jurnal Studi Islam}

ISSN 2723-0228

Volume 1 Nomor 2 Nopember 2020

Masa Pandemi Covid 19 Dalam Meningkatkan Aktivitas Dan Hasil Belajar Siswa Pada Mata Pelajaran Produk Kreatif Dan Kewirausahaan. Seminar Nasional Manajemen, Ekonomi dan Akuntasi Fakultas Ekonomi dan Bisnis UNP Kediri 19 September 2020. 


\section{REFERENSI}

Adit, Albertus. 2020. https://www.kompas.com/edu/read/2020/07/06/134752871/di-masa-pandemiorangtua-berperan-dalam-pendidikan-karakter-anak. Diakses 15Juli 2020.

Aji, Takhroji. 2020. https://bdkjakarta.kemenag.go.id/berita/pendidikan-karakter-di-masa-pandemimenjadi-tanggung-jawab-siapa? Diakses 14 Juli 2020

Fuadi, Ahmad Sahal. Penerapan Model Pembelajaran Problem Based Learning (PBL) Pada Masa Pandemi Covid 19 Dalam Meningkatkan Aktivitas Dan Hasil Belajar Siswa Pada Mata Pelajaran Produk Kreatif Dan Kewirausahaan. Seminar Nasional Manajemen, Ekonomi dan Akuntasi Fakultas Ekonomi dan Bisnis UNP Kediri 19 September 2020.

Gafuri, H. Akhmad. Pengembangan Model Manajemen Pendidikan Karakter Dengan Teknik Pendampingan Guru Pada Sekolah Dasar.Jurnal Paradigma, Volume 11, Nomor 2, Juli 2016.

Gunawan, Heri. Pendidikan Karakter, Konsep dan Implementasi, (Bandung: Alfabeta, 2014)

Hakam, K. A. 2005. Pendidikan Nilai. Bandung: CV Maulana.

https://www.merdeka.com/jakarta/anies-baswedan-pendidikan-karakter-bukan-sekadar-ilmupengetahuan.html. Diakses 19 Juli 2020

https://abdiguru.id/pemanfaatan-teknologi-dalam-pendidikan-karakter-di-sekolah. Diakses tanggal 30 Oktober 2020 pukul 16.00.

Kementerian Pendidikan Nasional. 2011. Panduan Pelaksanaan Pendidikan Karakter (Jakarta: Pusat Kurikulum dan Perbukuan)

Kuswandi, Yudi dan Emma Himayaturohmah PEMBUDAYAAN NILAI-NILAI ISLAMI DALAM MEMBANGUN KARAKTER BANGSA (Studi Kasus di Sekolah Menengah Kejuruan Negeri 1 Cimahi) . Tatar Pasundan: Jurnal Diklat Keagamaan Bandung. Vol. 12 (34)2018

Mulyana, R. 2004. Mengartikulasikan Pendidikan Nilai. Bandung: CV. Alfabeta.

Ramin, Karakteristik Pendidikan Karater Siswa Pada Jenjang Pendidikan Dasar. Tatar Pasundan: Jurnal Diklat Keagamaan. Vol. 12 (32) 2018

Sani, Ridwan Abdullah, 2014, Pembelajaran Santifik untuk Implementasi Kurikulum 2013, Jakarta: Bumi Aksara.

Subarto. MomentUM Keluarga Mengembangkan Kemampuan Belajar Peserta Didik Di Tengah Wabah Pandemi Covid-19. 'Adalah Jurnal Hukum dan Keadilan volume 4 nomor 12020.

Suparno. 2002. Keterampilan Dasar Menulis. Jakarta: Universitas Terbuka, Departemen Pendidikan Nasional.

Suyadi, 2015, Srategi Pembelajaran Pendidikan Karakter, Bandung: Remaja Rosdakarya, Cet. III.Hal. 134.

Taufikin. Pembentukan Karakter Melalui Pembelajaran Problem Based Learning. Jurnal ThufuLA Volume 5 Nomor 1 Januari - Juni 2017

Widoyoko, S. E. 2007. "Pengembangan Model Evaluasi Pembelajaran IPS di SMP", Disertasi. Yogyakarta: PPS UNY.

Zuchdi, Darmiyati dkk.2010. Pengembangan Model Pendidikan Karakter Terintegrasi Dalam Pembelajaran Bidang Studi Di Sekolah Dasar. Cakrawala Pendidikan Jurnal Ilmiah Pendidikan No. 3 Mei 2010

2003. Undang-Undang Sistem Pendidikan Nasional. Jakarta: CV. Eka jaya. 